DOI 10.14746/ssp.2018.2.4

\title{
Agnieszka SzPaK
}

Uniwersytet Mikołaja Kopernika w Toruniu

\section{Udział i rola kobiet w negocjacjach pokojowych}

Streszczenie: Rada Bezpieczeństwa ONZ wydała na przestrzeni ostatnich piętnastu lat kilka rezolucji dotyczących roli kobiet $\mathrm{w}$ zapobieganiu konfliktom oraz budowaniu pokoju. Pierwszą i przełomową była rezolucja 1325 (2000), w której podkreślono istotne znaczenie równego i pełnego uczestnictwa kobiet $\mathrm{w}$ zapobieganiu i rozwiązywaniu konfliktów, budowaniu i utrzymaniu pokoju. Udział kobiet w negocjacjach pokojowych czy szerzej działaniach na rzecz pokoju i bezpieczeństwa jest istotny m.in. dlatego, że istnieje o $35 \%$ większa szansa, że porozumienia pokojowe wynegocjowane z udziałem kobiet potrwają co najmniej 15 lat. Artykuł skupia się na instrumentach Rady Bezpieczeństwa ONZ w zakresie zapewnienia większego udziału kobiet w utrzymaniu pokoju i bezpieczeństwa oraz rezultatach wdrażania tych instrumentów.

Słowa kluczowe: negocjacje pokojowe, udział kobiet, budowanie pokoju, zapobieganie konfliktom, rezolucja 1325

\section{Wstęp}

R ardzo często porozumienia pokojowe są negocjowane przede wszystD kim przez mężczyzn, bez uwzględnienia lokalnej wiedzy i oczekiwań społecznych oraz udziału kobiet. Tradycyjnie procesy pokojowe koncentrowały się na zgromadzeniu przy stole rokowań walczących i politycznych decydentów, wśród których rzadko były kobiety. Jak słusznie zauważyła Grąca Machel, która była m.in. mediatorką w procesie pokojowym w Kenii w 2008 r., „kiedy przyznaje się pierwszeństwo walczącym stronom kosztem konsultacji z [...] większością społeczeństwa, przyznaje się im prawo do decydowania za innych, w gruncie rzeczy nagradzając ich za użycie siły zbrojnej” (O’Reilly, Ó Súilleabháin, Paffenholz, 2015, s. 14). Pamiętać należy, że porozumienia pokojowe nie tylko regulują zakończenie działań zbrojnych, ale kładą podwaliny pod powojenny porządek polityczny, społeczny i ekonomiczny. Stąd udział w nich kobiet jest konieczny. Kobiety i organizacje kobiece stanowią jeden z elementów społeczeństwa obywatelskiego. Społeczeństwo to z definicji jest różno- 
rodne; odzwierciedla podziały, a czasami nawet konkurencyjne interesy różnych grup. Organizacje społeczeństwa obywatelskiego służą jako kanały do wyrażania tych różnorodnych interesów. Społeczeństwo obywatelskie kojarzone jest w konsekwencji z pluralizmem - opinii, poglądów, perspektyw i uczestników. Stanowi ono przestrzeń dla aktywnego udziału jednostek i ich grup w rządzeniu; pozwala im wpływać na państwa w kierunku zwiększenia ich odpowiedzialności za własne działania (Caparini, 2005, s. 71). Dlatego też dla skuteczności procesu pokojowego udział przedstawicieli społeczeństwa obywatelskiego (przede wszystkim organizacji pozarządowych, w tym reprezentujących kobiety) jest konieczny (Wanis-St. John, Kew, 2008).

Kobiety nie stanowią homogenicznej grupy, a ich doświadczenia konfliktu zbrojnego i szczególne potrzeby w kontekście pokonfliktowej odbudowy są różnorodne (O'Rourke, 2014, s. 138). Kobiety nie są tylko biernymi obserwatorkami lub ofiarami. Odgrywały i odgrywają role także jako żołnierki, partyzatnki, część zorganizowanego społeczeństwa obywatelskiego, obrończynie praw człowieka, członkinie ruchu oporu i aktywne uczestniczki procesów budowania pokoju i odbudowy państwa (General recommendation No. 30 on women in conflict prevention, conflict and post-conflict situations, 2013, punkt 6). Mężczyźni to z reguły żołnierze/bojownicy i częściej niż kobiety giną bezpośrednio w walkach. Kobiety z kolei, częściej umierają w rezultacie naruszeń praw człowieka, załamania się porządku społecznego czy rozprzestrzeniania chorób zakaźnych (O’Reilly, Ó Súilleabháin, Paffenholz, 2015, s. 5). Skuteczność procesu pokojowego zależy od uwzględniania tej szerokiej bazy doświadczeń, w tym różnorodnych doświadczeń kobiet z okresu sprzed konfliktu, w trakcie konfliktu i z okresu po konflikcie. Kofi Annan, były Sekretarz Generalny ONZ, słusznie zauważył, że większy udział w procesie pokojowym organizacji społeczeństwa obywatelskiego, zwłaszcza kobiet, które są zazwyczaj marginalizowane podczas negocjacji, jest niezwykle istotny dla sukcesu procesu pokojowego (2004, s. 38). Od 2000 r., kiedy Rada Bezpieczeństwa ONZ uchwaliła rezolucję 1325 na temat kobiet, pokoju i bezpieczeństwa, ONZ wskazywała, że środowisko sprzyjające zawarciu porozumienia pokojowego musi się stać bardziej inkluzyjne i uwzględniać kobiety.

Problematyka tego artykułu dotyczy udziału kobiet w procesie pokojowym, w tym zwłaszcza w negocjacjach pokojowych. Celem artykułu jest wskazanie, że aktywna rola kobiet jest konieczna dla osiagnięcia prawidłowego przebiegu procesu pokojowego i skuteczności porozu- 
mienia pokojowego. Punkt 2 dotyczyć będzie uregulowań Konwencji o eliminacji wszelkich form dyskryminacji kobiet oraz całej palety rezolucji Rady Bezpieczeństwa ONZ dotyczących udziału i roli kobiet w zapobieganiu i rozwiązywaniu konfliktów zbrojnych oraz budowaniu pokoju. W punkcie 3 wskazane zostaną przykłady udziału kobiet w procesie pokojowym, a w punkcie 4 argumenty na rzecz tezy, że udział kobiet w negocjacjach pokojowych ma duże pozytywne znaczenie. Artykuł zamkną uwagi końcowe.

$\mathrm{W}$ artykule zastosowano metody badawcze, w pierwszym rzędzie instytucjonalno-prawną oraz, pomocniczo, analizy literatury. Przede wszystkim analizie poddano rezolucje Rady Bezpieczeństwa ONZ i różnego rodzaju studia i raporty będące poniekąd ich pokłosiem i starające się odpowiedzieć na pytanie o skuteczność ich implementacji.

\section{Konwencje i rezolucje}

Rada Bezpieczeństwa ONZ wydała na przestrzeni ostatnich piętnastu lat kilka rezolucji dotyczacych roli kobiet w zapobieganiu konfliktom oraz budowaniu pokoju, innymi słowy w szeroko pojętym procesie pokojowym. Negocjacje pokojowe są jednym z jego elementów. Pierwszą i przełomową była rezolucja 1325 (2000), w której podkreślono istotne znaczenie równego i pełnego uczestnictwa kobiet $\mathrm{w}$ zapobieganiu i rozwiązywaniu konfliktów, budowaniu i utrzymaniu pokoju. Rezolucja wezwała wszystkie państwa członkowskie do zapewnienia równego i pełnego udziału kobiet we wszystkich wysiłkach mających na celu utrzymanie i promocję pokoju i bezpieczeństwa. Dotyczy to wszelkich szczebli tego uczestnictwa - narodowego, regionalnego i na poziome instytucji międzynarodowych (preambuła, punkt 1). Podobny apel można znaleźć także w Deklaracji z Pekinu (Beijing Declaration) na zakończenie czwartej Światowej Konferencji Praw Kobiet (1995, punkty 141, 142). Rada Bezpieczeństwa wezwała także wszystkich aktorów zaangażowanych w negocjowanie i realizacje porozumień pokojowych (a więc nie tylko państwa), aby w tych działaniach uwzględniały udział i prawa kobiet (gender perspective), przede wszystkim szczególne potrzeby kobiet podczas repatriacji, rehabilitacji i pokonfliktowej odbudowy oraz środki wspierające lokalne inicjatywy pokojowe ze strony kobiet mające na celu rozwiązanie konfliktu, jak również środki uwzględniające udział kobiet $\mathrm{w}$ implementacji porozumień pokojowych. $\mathrm{W}$ ramach negocjacji poko- 
jowych, a następnie ich implementacji należy także podejmować środki mające zapewnić poszanowanie praw kobiet (rez. 1325, punkty 7 i 8a). Strony konfliktu zbrojnego powinny także podjąć szczególne środki mające chronić kobiety i dziewczęta przed przemocą seksualną, zwłaszcza gwałtem (rez. 1325, punkt 10). Rada Bezpieczeństwa zachęca wszystkie strony zaangażowane $\mathrm{w}$ planowanie rozbrojenia, demobilizacji i reintegracji, aby wzięły pod uwagę odmienne potrzeby byłych żołnierzy i bojowników - kobiet i mężczyzn (rez. 1325, punkt 13).

W rezolucji 1820 (2008) Rada Bezpieczeństwa wskazała na bezpośrednie powiązanie między przemocą seksualną wobec kobiet, stosowaną jako narzędzie wojny, a pokojem i bezpieczeństwem. Rezolucja ta podkreśla, że przemoc seksualna w czasie konfliktu zbrojnego stanowi zbrodnię wojenną i żąda od państw członkowskich podejmowania środków mających zapewnić ochronę osób cywilnych przed taką przemocą, włączając w to szkolenie sił zbrojnych i ich karanie (punkty 1, 3, 4). W rezolucji 1888 (2009), będącej kontynuacją rezolucji 1820, wskazano, że wszystkie strony konfliktu powinny chronić kobiety i dzieci przed przemoca, do której dochodzi w trakcie konfliktów zbrojnych. Sekretarz Generalny ONZ został zobowiązany do wyznaczenia Specjalnego przedstawiciela ds. przemocy seksualnej w czasie konfliktu zbrojnego (Special Representative of the Secretary-General on Sexual Violence in Conflict) (punkty 3-4). Obecnie Specjalną przedstawicielką jest Pramila Patten z Mauritiusa (http://www.un.org/sexualviolenceinconflict/aboutus/about-the-srsg/).

Kolejna rezolucja, 1889 (2009), apeluje o wzmocnienie udziału kobiet w procesach pokojowych. Preambuła powtarza stwierdzenia o potrzebie pełnego, równego i rzeczywistego udziału kobiet we wszystkich etapach procesu pokojowego z uwzględnieniem ich witalnej roli w zapobieganiu i rozwiązywaniu konfliktu i budowaniu pokoju. Potwierdza także kluczową rolę kobiet w przywróceniu tkanki społeczeństwa i podkreśla konieczność ich udziału w rozwijaniu i wdrażaniu strategii pokonfliktowych, tak aby uwzględnić perspektywę i potrzeby kobiet (preambuła). Rada Bezpieczeństwa wyraża także głębokie zaniepokojenie zbyt niską reprezentacją kobiet we wszystkich etapach procesu pokojowego, zwłaszcza bardzo niską liczbą kobiet zajmujących formalne stanowiska w procesie mediacji i podkreśla potrzebę zapewnienia, aby kobiety były mianowane na stanowiska decyzyjne, np. jako mediatorki wysokiego szczebla (preambuła). Najważniejsze postanowienie rezolucji dotyczy jednak wezwania państw członkowskich oraz międzynarodowych organizacji do podjęcia 
kroków w celu poprawy udziału kobiet we wszystkich etapach procesu pokojowego, zwłaszcza w rozwiązywaniu konfliktów, pokonfliktowym planowaniu i budowaniu pokoju, włączając w to wzmocnienie ich zaangażowania w podejmowanie decyzji na polu politycznym i ekonomicznym (punkt 1).

Rezolucja 1960 (2010) ponawia wszystkie wcześniejsze apele i nawoływania skierowane do państw członkowskich mające doprowadzić do zwiększonego uczestnictwa kobiet w zapobieganiu i rozwiązywaniu konfliktów oraz budowaniu pokoju (punkty 5-15). W najnowszych rezolucjach 2106 (2013) i 2122 (2013) Rada Bezpieczeństwa powtarza swoje wcześniejsze rezolucje. W rezolucji 2106 (2013) wskazuje m.in., że skuteczne zapobieganie i reagowanie na przemoc seksualną stosowaną jako narzędzie wojny może się znacznie przyczynić do utrzymania międzynarodowego pokoju i bezpieczeństwa, a udział kobiet w tym zapobieganiu i reagowaniu jest kluczowy (punkt 1). Z kolei w rezolucji 2122 (2013) powtórzono, że upodmiotowienie i równouprawnienie kobiet ma kluczowe znaczenie dla wysiłków zmierzających do utrzymania międzynarodowego pokoju i bezpieczeństwa. Podkreślono także, że utrzymujące się bariery dla pełnego wykonania rezolucji nr 1325 (2000) mogą zostać pokonane tylko poprzez rzeczywiste zobowiązanie się do wzmocnienia pozycji i praw kobiet, a także przez wspólne przywództwo, spójną akcję informowania i działania w celu zbudowania zaangażowania kobiet na wszystkich poziomach podejmowania decyzji (preambuła).

Rezolucje te wspierają realizację przepisów Konwencji ws. eliminacji wszelkich form dyskryminacji kobiet z 1979 r., takich zwłaszcza jak art. 7 dotyczący likwidacji dyskryminacji kobiet w życiu politycznym i publicznym oraz art. 8 zapewniający kobietom możliwość reprezentowania swoich rządów w stosunkach międzynarodowych (Dz. U. 1982, Nr 10, poz. 71). Komitet ds. Eliminacji Dyskryminacji Kobiet, powołany na mocy tej Konwencji, wydał w roku 2013 r. General recommendation (Zalecenie ogólne) nr 30 na temat kobiet i zapobiegania konfliktom, konfliktów i sytuacji pokonfliktowych. W Zaleceniu tym Komitet odwołał się do cytowanych wyżej art. 7 i 8 oraz wskazał, że stosownie do tego państwa strony powinny zapewnić udział kobiet w procesie pokojowym (punkty 44 i 45). Komitet zalecił także państwom stronom, aby zapewniły, że kobiety i organizacje społeczeństwa obywatelskiego zajmujące się prawami kobiet zostaną włączone do negocjacji pokojowych i w pokonfliktową odbudowę oraz, że kobiety uzyskają szkolenie w zakresie umiejętności przywódczych w celu zapewnienia ich skutecznego udziału 
w pokonfliktowych procesach politycznych (punkt 46). Również państwa strony, które nie biorą udziału w konfliktach zbrojnych, ale uczestniczą w procesie ich rozwiązywania powinny włączyć kobiety do negocjacji i mediacji (punkt 47).

\section{Weryfikacja - przykłady z praktyki}

W tej części wskazane zostanie kilka przykładów negocjacji pokojowych, w których kobiety brały udział i jakie były tego efekty. Między rokiem 1992 a 2011 tylko 2\% mediatorów i 9\% negocjatorów w formalnym procesie pokojowym było kobietami. Tylko 7\% porozumień pokojowych podpisanych między 1990 a 2010 rokiem zawierało przepisy dotyczące równości płciowej lub praw kobiet (O’Reilly, Ó Súilleabháin, Paffenholz, 2015, s. 2; por. O’Rourke, 2014, s. 146). Według innych źródeł, w latach 1990-2000 tylko 11\% porozumień pokojowych zawierało regulacje dotyczące kobiet. Od przyjęcia przez Radę Bezpieczeństwa ONZ rez. 1325 procent ten wzrósł do $27 \%$. Natomiast w sytuacji, kiedy ONZ wspierała proces pokojowy odsetek ten wynosił nawet 67\% (Preventing Conflict, 2015, s. 14). Parlament Europejski zaleca, aby procent kobiet biorących udział w negocjacjach pokojowych wynosił co najmniej 40\% (2006, s. 9).

Jednym z budzących większe emocje procesów pokojowych jest ten w Kolumbii, trwający już od dłuższego czasu. W najbardziej znanej grupie zbrojnej FARC (Rewolucyjne Siły Zbrojne Kolumbii) ok. 40\% partyzantów było kobietami, a w przypadku ELN (Armia Wyzwolenia Narodowego) kobiety stanowiły między 1/4 a 1/3 składu (Bouvier, 2016, s. 4). Jedynie kilka kobiet było zaangażowanych w negocjacje pokojowe w Kolumbii. W efekcie procesu pokojowego z lat 1990-1994 rząd Kolumbii zawarł porozumienie pokojowe z niektórymi grupami zbrojnymi. Tylko jedna kobieta, członkini grupy partyzanckiej, widnieje jako sygnatariuszka tych porozumień. Pozostałe osoby, negocjatorzy, świadkowie i gwaranci, to mężczyźni. W rozmowach pokojowych z ELN w latach 2005-2007 kobiety w ogóle nie brały udziału. Podobnie było w przypadku wielu rund negocjacji pokojowych z FARC, kiedy to tylko kilka kobiet brało w nich udział (np. w latach 1998-2002 z ramienia rządu negocjatorkami były Maria Emma Mijia i Ana Teresa Bernal. Po stronie FARC negocjowała Mariana Páez) (Bouvier, 2016, s. 17). W czasie negocjacji z FARC, które rozpoczęły się w Norwegii (po 2012 r.) wszyst- 
kie stanowiska zajmowali mężczyźni, a jedyną kobietą była norweska moderatorka. Późniejsze formalne rozmowy były natomiast prowadzone na Kubie. Każda strona mogła mieć do dziesięciu negocjatorów z pełnią praw negocjacyjnych. Wszyscy negocjatorzy byli mężczyznami, z wyjątkiem jednej kobiety, Tanji Nijmeijer znanej także jako Alexandra Nariño (po stronie FARC) (Bouvier, 2016, s. 19). Mimo że z czasem, pod presją kolumbijskich organizacji kobiecych, sytuacja się poprawiła, to jednak przez większość czasu kobiety były marginalizowane i niedoceniane jako partnerzy w procesie pokojowym. Z drugiej strony przekonanie o nikłej roli kobiet w procesie pokojowym jest mylące, gdyż kobiety brały udział w różnych innych czynnościach „wokół stołu negocjacyjnego”. Kolumbijskie kobiety kształtowały opinię publiczną i wspierały konkretne propozycje rozwiązania konfliktu. Organizacje kobiece naciskały na strony negocjacji, aby nie odchodziły od stołu rokowań bez osiagnięcia porozumienia kończącego konflikt, kobiety uczestniczyły w przeróżnych konferencjach, grupach roboczych i inicjatywach badawczych (Bouvier, 2016, s. 19). W listopadzie 2013 r. rząd nominował dwie kobiety jako pełnomocne negocjatorki: Nigerię Rentieria i Marię Paulinę Riveros (Bouvier, 2016, s. 20). W kwietniu 2013 r. również FARC mianowała na swoją negocjatorkę Victorię Sandino. Liczba kobiet w zespole negocjacyjnym FARC rosła i w lutym 2015 r. osiągnęła ponad 40\% (Bouvier, 2016, s. 20). W czasie negocjacji w Hawanie kobiety z delegacji obu stron analizowały i przygotowywały propozycje, memoranda, przemowy i stanowiska; zespoły doradcze również składały się z kobiet. Mimo że tego typu działania były mniej widoczne niż bezpośredni udział w negocjacjach pokojowych, to wciąż pozwoliły one kobietom wpływać na przebieg procesu pokojowego (Bouvier, 2016, s. 21). W tym przypadku negocjacje zakończyły się sukcesem. W dniu 26 sierpnia 2016 r. zawarto porozumienie pokojowe (Final Accord for the Termination of the Conflict and the Construction of a Stable and Lasting Peace in Colombia) (Summary of Colombia's Agreement to End Conflict and Build Peace, 2016; Sánchez, 2016).

Innym pozytywnym przykładem jest proces pokojowy na Filipinach. W III 2014 r. rząd Filipin i Islamski Front Wyzwolenia Moro podpisały porozumienie pokojowe, a kobiety stanowiły 50\% zespołu negocjacyjnego i 25\% sygnatariuszy (O’Reilly, Ó Súilleabháin, Paffenholz, 2015, s. 19). Wcześniej w czasie rozmów pokojowych w Oslo w 2011 r. odsetek kobiet wśród delegatów był najwyższy ze wszystkich 31 procesów pokojowych z lat 1992-2011 (O’Reilly, Ó Súilleabháin, Paffenholz, 2015, s. 20; Preventing Conflict..., s. 43). 
Z kolei w negocjacjach pokojowych dotyczących Syrii, które toczyły się w Genewie, trzech na pięciu członków obu zespołów negocjacyjnych (rządu i opozycji) było kobietami. Kobiety także doradzały zespołowi negocjacyjnemu opozycji. Mediator z ramienia ONZ korzystał z usług rady doradczej złożonej z dwunastu syryjskich kobiet i jednej międzynarodowej ekspertki ds. gender (Women's Inclusion in the Syria Peace Talks, 2016). W odniesieniu do Syrii, w tzw. Komunikacie z Genewy z 2012 r., który stanowił wcześniejszą próbę rozwiązania konfliktu w Syrii, wskazywano na konieczność zapewnienia udziału kobiet na każdym etapie procesu pokojowego (s. 3). Niestety w tym przypadku wciąż nie osiagnięto porozumienia (Szpak, 2016, s. 229-244).

W procesie pokojowym w Mali udział brali mediatorzy m.in. z ONZ, Unii Afrykańskiej i Unii Europejskiej, a więc wielostronnych organizacji międzynarodowych, którym zależy na zwiększonej reprezentacji kobiet w procesach pokojowych. Jednak, główny mediator, Algieria, nie był przekonany co do znaczenia udziału kobiet w negocjacjach pokojowych. Dyplomaci biorący udział $\mathrm{w}$ rozmowach byli mężczyznami powyżej 50. roku życia. Wśród stu delegatów z trzech delegacji: rządu Mali, grup zbrojnych blisko związanych z rządem oraz opozycyjnych było jedynie pięć kobiet. Tylko UE i ONZ miały w swoich zespołach negocjacyjnych kobiety, które pełniły role ekspertek lub doradczyń (O’Reilly, Ó Súilleabháin, Paffenholz, 2015, s. 9; Preventing Conflict..., s. 48).

Warto przytoczyć także starszy przykład Irlandii Północnej i udziału kobiet $\mathrm{w}$ procesie pokojowym. W negocjacjach prowadzących do zawarcia porozumienia wielkopiątkowego z 1998 r. (Good Friday) początkowo kobiety nie miały swojej reprezentacji. To spowodowało, że kilka zaangażowanych kobiet stworzyło partię polityczną o nazwie Northern Ireland Women's Coalition, która była jedną z dziesięciu partii biorących udział w negocjacjach. Mimo że pozycja kobiet była słabsza i były one mniej liczne niż mężczyźni, kobiety wciąż były w stanie zabezpieczyć w porozumieniu wielkopiątkowym pewne postanowienia dotyczące ich praw (O’Reilly, Ó Súilleabháin, Paffenholz, 2015, s. 9; McWilliams, on line; Preventing Conflict..., s. 50).

Na tle tych przykładów można także wskazać bariery dla udziału kobiet w negocjacjach pokojowych. Pierwszą jest tzw. bariera konceptualna, zgodnie z którą porozumienia pokojowe mają zakończyć wojnę, a więc tylko aktorzy wojenni (walczący) biorą w nich udział. Jednak jeśli zmieni się koncepcję rozmów pokojowych i skupi się nie tylko na zakończeniu działań zbrojnych (co odpowiada koncepcji negatywnego pokoju), ale 
także na budowaniu pokoju (co mieści się w ramach koncepcji pozytywnego pokoju) wtedy szansa na włączenie kobiet staje się większa (O’Reilly, Ó Súilleabháin, Paffenholz, 2015, s. 22; O’Rourke, 2014, s. 132).

Bariera techniczna oznacza, że ze względu na ograniczone doświadczenie kobiet w negocjacjach nie powinny one brać w nich udziału. Jednak ta przeszkoda może zostać pokonana poprzez szkolenia i budowanie zdolności przywódczych i negocjacyjnych kobiet. Z drugiej strony, argumentów takich nie podnosi się wobec mężczyzn, niekiedy niemających odpowiedniego doświadczenia czy przeszkolenia (O’Reilly, Ó Súilleabháin, Paffenholz, 2015, s. 22). W raporcie dotyczącym realizacji rez. 1325 stwierdzono, że powtarzane stwierdzenia o tym, że kobietom brak umiejętności i doświadczenia są kolejnym przejawem wykluczenia kobiet z procesu pokojowego (Preventing Conflict..., s. 56).

Wreszcie bariera polityczna powoduje, że brakuje przekonania o znaczeniu kobiet dla podejmowania decyzji, stąd, niesłusznie, ich udział w rozmowach pokojowych jest uznawany za niepotrzebny albo nic nieznaczący (O’Reilly, Ó Súilleabháin, Paffenholz, 2015, s. 22). Ponadto, kobiety muszą sobie czasami poradzić z pewnymi logistycznymi problemami takimi jak konieczność zorganizowania opieki nad dzieckiem, konieczność zdobycia środków finansowych na podróż lub potrzeba zapewnienia sobie bezpieczeństwa, a poradzenie sobie z nimi ma bezpośredni wpływ na udział kobiet w procesie pokojowym (O’Reilly, Ó Súilleabháin, Paffenholz, 2015, s. 30).

\section{Znaczenie udziału kobiet w negocjacjach pokojowych}

W 2015 r. ukazały się wyniki badań Thani Paffenholz dotyczące włączenia kobiet w proces pokojowy oraz ich wpływu na jakość i trwałość porozumień pokojowych. Projekt nosił nazwę „Broadening Participation Project" (Broadening Participation in Track One Peace Negotiations). W toku badań 40 przypadków konfliktów zbrojnych i procesów pokojowych, w których to procesach uczestniczyły kobiety, analizie poddano wpływ kobiet i ich grup na jakość i trwałość porozumień pokojowych oraz warunki, w których kobiety mogą skutecznie wpływać na proces pokojowy. Analizie poddano 182 porozumienia pokojowe (O'Reilly, Ó Súilleabháin, Paffenholz, 2015, s. 10 i 33).

Badaczka ta wskazała, że udział kobiet w procesie pokojowym może przybierać różne formy. Poza bezpośrednim udziałem w negocjacjach 
może to być na przykład status obserwatora, udział w konsultacjach, komisjach czy też warsztatach rozwiązywania problemów, publiczne podejmowanie decyzji (np. w drodze referendum) czy działania zbiorowe (takie jak protesty czy strajki) (O’Reilly, Ó Súilleabháin, Paffenholz, 2015, s. 13). W bezpośrednich negocjacjach kobiety mogą uczestniczyć jako mediatorki i członkinie delegacji negocjacyjnych. Ta forma daje kobietom bezpośrednią i najsilniejszą możliwość wpływania na przebieg negocjacji, treść porozumień pokojowych, a przez to także na kształt pokonfliktowego społeczeństwa i życia publicznego (O’Reilly, Ó Súilleabháin, Paffenholz, 2015, s. 14). Warto jednak pamiętać, że bezpośredni udział w rozmowach pokojowych nie zawsze oznacza rzeczywisty wpływ na podejmowanie decyzji. Bardzo często nawet jeśli w rozmowach biorą udział kobiety, to decyzje podejmuje mała grupa mężczyzn. Na przykład w latach 2001-2003 w ramach tzw. Międzykongijskiego Dialogu z udziałem rządu Demokratycznej Republiki Konga, grup zbrojnych oraz nieuzbrojonej opozycji, w rozmowach pokojowych uczestniczyły także organizacje społeczeństwa obywatelskiego, w tym grupy kobiece. Jednak nie wszystkie te grupy miały równy głos (O’Reilly, Ó Súilleabháin, Paffenholz, 2015, s. 15).

Z kolei, przykładowo, status obserwatora stanowi bardziej nieformalny mechanizm umożliwiający pewien udział w negocjacjach pokojowych oraz pozwala na przekazanie informacji lub stanowiska w danej sprawie. Obserwatorzy nie mają jednak formalnie wpływu na podejmowane decyzje (O’Reilly, Ó Súilleabháin, Paffenholz, 2015, s. 15). Konsultacje dają możliwość wpływania na negocjacje bez bezpośredniego w nich udziału. Jest to najbardziej rozpowszechniona forma szerszego udziału w procesie pokojowym. W niektórych przypadkach konsultacje mogą zostać oficjalnie uznane za część procesu negocjacji. Podczas procesu pokojowego w Afganistanie w 2001 r. i w Gwatemali w latach 1994-1996 kobiety odgrywały ważną rolę w ramach Oficjalnych Forów Konsultacyjnych. Powołano je w celu ułatwienia szerokiego udziału aktorów politycznych i społecznych, a tym samym także zwiększenia legitymizacji i wiarygodności procesu pokojowego. Konsultacje mogą być również mniej oficjalne, kiedy to na przykład same kobiety powołują organy konsultacyjne, np. podczas negocjacji w Kenii w 2008 r. (pod auspicjami UA) (O'Reilly, Ó Súilleabháin, Paffenholz, 2015, s. 16).

Udział kobiet nie jest jedynym czy decydującym czynnikiem mającym wpływ na osiagnięcie porozumienia; naturalnie takie porozumienia były zawierane bez udziału kobiet. Jednak badania wykazały, że włączenie ko- 
biet w proces pokojowy nie tylko nie utrudnia ani nie zakłóca zawierania takich porozumień, a wprost przeciwnie, jest związane ze zwiększonym prawdopodobieństwem osiagnięcia porozumienia pokojowego. $\mathrm{Z}$ badań Thani Puffenholz wynika, że w żadnym przypadku udział organizacji kobiecych nie wpłynął negatywnie na proces pokojowy (O'Reilly, Ó Súilleabháin, Paffenholz, 2015, s. 11).

Kobiety zabiegały o uregulowanie $\mathrm{w}$ porozumieniach pokojowych praw kobiet i równości płci, np. w Burundi kobiety doprowadziły do włączenia do porozumień pokojowych przepisów dotyczących swobody zawarcia małżeństwa i prawa wyboru partnera. Jak więc widać, kiedy kobiety uczestniczyły i były w stanie wywierać wpływ na negocjacje, prawdopodobieństwo zawarcia porozumienia pokojowego było większe, a teksty porozumienia zawierały więcej uregulowań dotyczących praw kobiet i równości płci (O’Reilly, Ó Súilleabháin, Paffenholz, 2015, s. 11-12).

Inny wniosek był taki, że udział grup kobiet w procesie pokojowym był ściśle związany z implementacją porozumień pokojowych, w tym znaczeniu, że taki udział zwiększa trwałość tych porozumień. Oceniając obecność kobiet jako negocjatorek, mediatorek, świadków i sygnatariuszek 182 porozumień pokojowych z lat 1989-2011 oraz długość ich trwania, Laurel Stone ustaliła, że udział kobiet wywierał statystycznie znaczący pozytywny wpływ na trwanie pokoju. Kiedy kobiety były włączane w proces pokojowy, będące jego efektem porozumienie pokojowe ma 20\% więcej szans przetrwać co najmniej 2 lata. Udział kobiet ma jeszcze większy długofalowy wpływ: porozumienia pokojowe, w których powstaniu uczestniczyły kobiety, mają $35 \%$ więcej szans przetrwać nawet 15 lat (O’Reilly, Ó Súilleabháin, Paffenholz, 2015, s. 12 i 34; Preventing Conflict..., s. 41-42).

\section{Uwagi końcowe}

Proces pokojowy to nie tylko samo podpisanie porozumienia pokojowego. Proces ten daje możliwość dogłębnego i dokładnego rozwiązania problemów leżących u podłoża konfliktu zbrojnego, takich jak nierówności społeczne i niesprawiedliwość (Cahn, Haynes i Ni Aolain, 2010, s. 345). W procesie tym konieczne jest uwzględnienie perspektywy i potrzeb kobiet. Co istotne, te perspektywy i potrzeby powinny określić same kobiety, a nie tylko mężczyźni, gdyż konflikty w odmienny sposób dotykają kobiet i mężczyzn (Bouvier, 2016, s. 27; Zgromadzenie Parla- 
mentarne Rady Europy, rez. 1385 (2004), punkt 7). Formalne negocjacje pokojowe to nie jedyna możliwość dla kobiet wzięcia udziału w procesie pokojowym, choć istotne jest, aby były one obecne i aktywne przy stole negocjacyjnym. Ogólnie, udział kobiet w negocjacjach pokojowych, i szerzej całym procesie pokojowym, jest kluczowy dla ich efektywności i trwałości oraz daje większe szanse na skuteczną implementację porozumień pokojowych. Również dlatego, że bezpieczeństwo jest inaczej rozumiane przez kobiety, głównie dlatego, że zagrożenia dla bezpieczeństwa kobiet, poza tym, że wspólne, są także odmienne od zagrożeń dla bezpieczeństwa mężczyzn. W związku z tym priorytety kobiet w czasie negocjacji pokojowych są inne od priorytetów mężczyzn. Kobiety często poszerzają zakres zagadnień podlegających negocjacjom o takie kwestie jak rozwój, prawa człowieka oraz bezpieczeństwo. Innymi słowy, kobiety przywiązują większą wagę do zagadnień będących trzema filarami ONZ (O’Reilly, Ó Súilleabháin, Paffenholz, 2015, s. 6). Uwzględnienie tych zagadnień pozwala na zbudowanie trwałego pokoju i powrót do zasady rządów prawa.

Kobiety stanowiące zwykle połowę ludności mają prawo być reprezentowane w procesach decyzyjnych, które mogą mieć wpływ na ich życie, w tym negocjacjach pokojowych. Rada Bezpieczeństwa ONZ również potwierdziła znaczenie większego udziału kobiet w rozwiązywaniu konfliktów i budowaniu pokoju. Jednak pomimo rezolucji Rady Bezpieczeństwa, wykreowanie klimatu politycznego korzystnego dla równego udziału kobiet w negocjacjach pokojowych wciąż pozostaje znaczącym wyzwaniem i postęp w tej dziedzinie jest bardzo powolny (McWilliams, s. 9; O’Reilly, Ó Súilleabháin, Paffenholz, 2015, s. 2). Wielu negocjatorów i decydentów jest wciąż niechętnych udziałowi kobiet w negocjacjach pokojowych, głównie z powodu obaw o efektywność tych negocjacji oraz rzekomego braku dowodów pozytywnej roli kobiet w procesie pokojowym (O’Reilly, Ó Súilleabháin, Paffenholz, 2015, s. 2). Jak jednak wskazano wyżej, dziś takie dowody już istnieją.

Badania przywoływane w tym artykule dowodzą, że udział kobiet w negocjacjach pokojowych, lub szerzej w procesie pokojowym, zwiększa szanse na osiagnnięcie porozumienia pokojowego, a długoterminowo zwiększa trwałość tego porozumienia. Włączenie kobiet w proces pokojowy nie daje gwarancji, że prawa kobiet zostaną uwzględnione w porozumieniu pokojowym, jednak z całą pewnością daje większe prawdopodobieństwo tegoż. Alaa Murabit słusznie zauważyła, że w procesach pokojowych neguje się rolę połowy ludności, czyli kobiet, a później wyra- 
ża się zdziwienie, że pokój nie jest trwały (Preventing Conflict..., s. 24). Dlatego należy podejmować kroki polityczne i prawne mające zwiększyć udział kobiet w podejmowaniu decyzji w zakresie budowania pokoju.

\section{Bibliografia}

Beijing Declaration and Platform for Action (1995), http://www.un.org/womenwatch/ daw/beijing/pdf/BDPfA\%20E.pdf.

Biuro Specjalnego przedstawiciela ONZ ds. przemocy seksualnej w konflikcie zbrojnym, http://www.un.org/sexualviolenceinconflict/about-us/about-the-srsg/.

Bouvier V. M. (2016) Gender and the Role of Women in Colombia's Peace Process, UN Women Background Paper, United States Institute of Peace.

Broadening Participation in Track One Peace Negotiations, http://graduateinstitute.ch/ home/research/centresandprogrammes/ccdp/ccdp-research/clusters-andprojects-1/participatory-peace-processes-an/broadening-participation-in-trac.html.

Cahn N., Haynes D., Ni Aolain F. (2010), Returning Home: Women in Post-Conflict Societies, „Baltimore Law Review”, nr 39, s. 339-369.

Caparini M. (2005), Enabling Civil Society in Security Sector Reconstruction, w: Security Governance in Post-Conflict Peacebuilding, red. A. Bryden, H. Hänggi, s. 69-91, Geneva Centre for the Democratic Control of Armed Forces, Genewa.

Committee on the Elimination of Discrimination against Women (2013), General recommendation No. 30 on women in conflict prevention, conflict and postconflict situations, http://www.ohchr.org/Documents/HRBodies/CEDAW/ GComments/CEDAW.C.CG.30.pdf.

Diaz F. A., Robledo V. M. (2016), Uncertainty, Peace Agreements, and Public Participation in Colombia, http://www.warscapes.com/opinion/uncertainty-peaceagreements-and-public-participation-colombia.

Geneva Communiqué Action Group for Syria Final Communiqué (2012), aneks II do rezolucji Rady Bezpieczeństwa nr 2118 (2013) z 27 września 2013 r., http:// www.un.org/en/sc/documents/resolutions/.

Konwencja ws. Eliminacji wszelkich form dyskryminacji kobiet (1979), Dz. U. 1982, Nr 10, poz. 71.

McWilliams M., Women at the Peace Table: The Gender Dynamics of Peace Negotiations, https://papers.ssrn.com/sol3/papers.cfm?abstract_id=2719156.

O’Reilly M., Ó Súilleabháin A., Paffenholz T. (2015), Reimagining Peacemaking: Women's Role in Peace Processes, https://www.ipinst.org/wp-content/uploads/2015/06/IPI-E-pub-Reimagining-Peacemaking.pdf.

O'Rourke C. (2014). 'Walk[ing] the halls of Power'? Understanding Women's Participation in International Peace and Security, „Melbourne Journal of International Law", nr 15, s. 128-154.

Parlament Europejski (2006), Report on the situation of women in armed conflicts and their role in the reconstruction and democratic process in post-conflict coun- 
tries, http://www.europarl.europa.eu/sides/getDoc.do?type=REPORT\&reference $=$ A6-2006-0159\&language $=\mathrm{EN}$.

Preventing Conflict, Transforming Justice, Securing the Peace. A Global Study on the Implementation of United Nations Security Council resolution 1325, http://www.peacewomen.org/sites/default/files/UNW-GLOBAL-STUDY-1325-2015\%20(1).pdf.

Rezolucja Rady Bezpieczeństwa ONZ 1325 (2000), http://www.un.org/en/sc/documents/resolutions/.

Rezolucja Rady Bezpieczeństwa ONZ 1820 (2008), http://www.un.org/en/sc/documents/resolutions/.

Rezolucja Rady Bezpieczeństwa ONZ 1888 (2009), http://www.un.org/en/sc/documents/resolutions/.

Rezolucja Rady Bezpieczeństwa ONZ 1889 (2009), http://www.un.org/en/sc/documents/resolutions/.

Rezolucja Rady Bezpieczeństwa ONZ 1960 (2010), http://www.un.org/en/sc/documents/resolutions/.

Rezolucja Rady Bezpieczeństwa ONZ 2122 (2013), http://www.un.org/en/sc/documents/resolutions/.

Sánchez C. F. (2016), Manipulating Truths: Media Coverage, Democracy, and the Colombian Referendum, https://justiceinconflict.org/2016/10/12/manipulating-truths-media-coverage-democracy-and-the-colombian-referendum/.

Summary of Colombia's Agreement to End Conflict and Build Peace (2016), http:// www.altocomisionadoparalapaz.gov.co/herramientas/Documents/summaryof-colombias-peace-agreement.pdf.

Szpak A. (2016), Syria - nowy plan pokojowy i jego szanse na sukces, „Studia Polityczne", nr 3, s. 229-244.

UN Secretary General (2004), A more secure world: Our shared responsibility. Report of the High-level Panel on Threats, Challenges and Change, http://www. un.org/en/peacebuilding/pdf/historical/hlp_more_secure_world.pdf.

Wanis-St. John A., Kew D. (200), Civil society and Peace Negotiations: Confronting Exclusion, „International Negotiation”, nr 13, s. 11-36.

Women's Inclusion in the Syria Peace Talks, https://www.inclusivesecurity. org/2016/03/10/infographic-womens-inclusion-in-the-syria-peace-talks/.

Zgromadzenie Parlamentarne Rady Europy, Rezolucja 1385 (2004) Conflict prevention and resolution: the role of women, http://assembly.coe.int/nw/xml/ XRef/Xref-XML2HTML-EN.asp?fileid=17233\&lang=en.

\section{Women's role and participation in peace negotiations}

\section{Summary}

The UN Security Council issued several resolutions over the last fifteen years regarding the role of women in conflict prevention and peacebuilding. Resolution 1325 
(2000) came first and marked a watershed stressing the importance of equal and full participation of women in the prevention and resolution of conflicts and building and maintaining peace. The participation of women in peace negotiations or broader activities for peace and security is important, among other things, because there is a $35 \%$ greater chance that peace agreements negotiated by women will last at least 15 years. The article focuses on the UN Security Council instruments to ensure greater participation of women in maintaining peace and security and the results of implementing these instruments.

Key words: peace negotiations, women's participation, peacebuilding, conflict prevention, resolution 1325 
